\begin{tabular}{|c|c|c|c|}
\hline $\begin{array}{l}\text { A CASE } \\
\text { Study }\end{array}$ & $\begin{array}{r}\text { ADVANCE RESEARCF } \\
\text { volume } 8 \mid \text { Issue } 2 \mid \text { De }\end{array}$ & $\begin{array}{l}\text { OCIAL SCIENCE } \\
-2231-6418\end{array}$ & \\
\hline $0=$ & DOI: 10.15740/HAS/ARJSS/8.2/374-378 & Visit us : www.researchjournal.co.in & \\
\hline
\end{tabular}

\title{
Effectiveness of social security net works- Myths and realities
}

V. Vijaya Lakshmi* and M. Milcah Paul ${ }^{1}$

AICRP-H.Sc., PG and RC, Professor Jayashankar Telangana State Agricultural University, HYDERABAD (TELANGANA) INDIA ${ }^{1}$ Department of RMCS, College of Home Science, Professor Jayashankar Telangana State Agricultural University, HYDERABAD (TELANGANA) INDIA

\section{ARTICLE INFO :}

Received : $\quad 11.05 .2017$

Accepted : $\quad 26.11 .2017$

\section{KEY WORDS :}

Social security net, OECD

countries, CLMV countries, Welfare programmes

HOW TO CITE THIS ARTICLE : Lakshmi, V. Vijaya and Paul, M. Milcah (2017). Effectiveness of social security net works- Myths and realities. Adv. Res. J. Soc. Sci., 8 (2) : 374-378, DOI: 10.15740/HAS/ARJSS/8.2/374-378.

\section{ABSTRACT}

The social safety net is a collection of services provided by the state or government sector for the welfare of poor people which include welfare programmes, unemployment benefits, elderly people benefits, healthcare, homeless shelters, and sometimes subsidized services such as public transport, which prevent individuals from falling into poverty. The programmes protect the families from the impact of economic shocks, natural disasters, and other unexpected crises; ensuring that children grow up healthy, well-fed, and can stay in school and learn; empowering women and girls; and creating jobs. Social safety nets come in many forms like cash, food, healthcare, housing, household goods or education for children etc. According to the State of Social Safety Nets 2015 statistics, more than 1.9 billion people in 136 low and middle-income countries are now on beneficiary rolls of social safety net programmes. Different countries have different social safety nets to meet the needs of people. Average social expenditure among OECD (Organization for Economic Cooperation and Development) countries was over 21 per cent of GDP in 2014. OECD countries operate different programmes like minimum income programme, housing benefits, family benefits, benefits for lone parents, employment -conditional benefits for able bodied people, child care benefits. The average developing country spends 1.6 per cent of GDP on social safety nets. In Sub-Saharan Africa and South Asia, where most of the global poor live, social safety nets cover just one-tenth and onefifth of the poorest 20 per cent of the population, respectively. The world's five largest social safety net programmes are all in middle-income countries (China, India, South Africa and Ethiopia) and reach over 526 million people.India spends about 0.72 per cent of the Gross National Product (GDP) on social safety net programmes. Pakistan and Bangladesh - spend a higher proportion on social safety net, i.e. 1.89 per cent and 1.09 per cent. In Brazil, under "BolsaFamilia" programme 53 per cent of Brazil's poor (or the bottom quintile) are covered. Mexico established its own conditional cash transfer programme, known as Prospera has been credited with improving education levels, strengthening nutritional status, and reducing poverty. Elements of Prospera have been replicated in more than 50 countries. In cities of China, there are different pension systems for civil servants, public services workers, urban employees and urban residents. Canada provides transfer payments for medicare and public education.The CLMV countries i.e., Cambodia, Laos, Myanmar, and Vietnam have their own framework for food security and social safety nets, as they are heterogeneous 